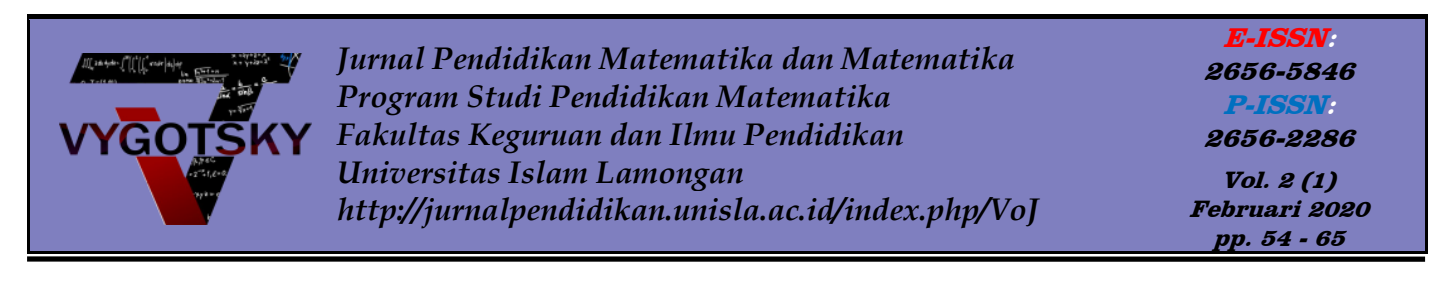

\title{
SCAFFOLDING SEBAGAI UPAYA MENGATASI KESALAHAN MATEMATIKA SISWA KELAS VIII DI SMP NEGERI 5 MEUREUBO
}

\section{(SCAFFOLDING AS AN EFFORT T OVERCOME THE MATHEMATICS ERRORS OF VIII th GRADE STUDENTS IN $5^{\text {th }}$ MEUREUBO JUNIOR HIGH SCHOOL)}

\author{
Dian Kristanti ${ }^{1}$ \\ 1STKIP Bina Bangsa Meulaboh, diankristanti56@gmail.com
}

\begin{tabular}{|c|c|}
\hline Info Artikel & Abstract \\
\hline $\begin{array}{l}\text { Received Feb 22, } 2020 \\
\text { Revised Feb 22, } 2020 \\
\text { Accepted Feb 26, } 2020\end{array}$ & $\begin{array}{l}\text { This study aims to describe students' mathematical errors } \\
\text { and describe efforts to provide scaffolding to help overcome } \\
\text { these errors. This research method uses a two-phase mixed } \\
\text { method, or better known as Explanatory Design with } \\
\text { participants. The research instruments used included: }\end{array}$ \\
\hline Kata Kunci: & $\begin{array}{l}\text { validation sheets, test questions sheets, and interview guide } \\
\text { sheets. The study was conducted on } 30 \text { students of class }\end{array}$ \\
\hline Kesalahan Siswa & VIII at Meureubo State Junior High School 5 in West Aceh \\
\hline Masalah Matematika & Regency in the odd semester of 2018. The results showed \\
\hline Aljabar & that students' errors in the aspect of story problems had the \\
\hline Scaffolding & $\begin{array}{l}\text { largest percentage of errors (81\%), followed by algebraic } \\
\text { forms ( } 72 \%) \text {, variables }(70 \%) \text {, and equations }(45 \%) \text {. After } \\
\text { giving scaffolding, the six students understood the location } \\
\text { of their mistakes and were able to solve the questions } \\
\text { correctly. }\end{array}$ \\
\hline
\end{tabular}

\footnotetext{
Cara merujuk artikel

ini:

Kristanti, D. (2020).

Scaffolding sebagai Upaya

Mengatasi Kesalahan

Matematika Siswa Kelas

VIII di SMP Negeri 5

Meureubo. Vygotsky: Jurnal

Pendidikan Matematika dan

Matematika, 2 (1), pp. 54-65

Diunduh dari https:/ /

jurnalpendidikan.

unisla.ac.id/index.php/VoJ

/article/view/193/pdf
}

\begin{abstract}
Abstrak
Penelitian ini bertujuan untuk mendeskripsikan kesalahan matematika siswa serta mendeskripsikan upaya pemberian scaffolding untuk membantu mengatasi kesalahan tersebut. Metode penelitian ini menggunakan mixed method dua fase, atau yang lebih dikenal dengan Explanatory Design dengan partisipan. Instrumen penelitian yang digunakan antara lain: lembar validasi, lembar soal tes, dan lembar pedoman wawancara. Penelitian dilakukan terhadap 30 siswa kelas VIII di SMP Negeri 5 Meureubo Kabupaten Aceh Barat pada semester ganjil 2018. Hasil penelitian menunjukkan kesalahan siswa pada aspek soal cerita mempunyai persentase kesalahan terbesar (81\%), diikuti oleh bentuk aljabar $(72 \%)$, variabel $(70 \%)$, dan persamaan $(45 \%)$. Setelah pemberian scaffolding, keenam siswa tersebut menjadi paham letak kesalahannya dan mampu menyelesaikan pertanyaan yang diberikan dengan tepat.
\end{abstract}

Copyright (C) 2020 Vygotsky: Jurnal Pendidikan Matematika dan Matematika. All right reserved 


\section{PENDAHULUAN}

Kesalahan siswa merupakan suatu hal yang sering ditemui dalam pembelajaran matematika, baik ketika siswa sedang memahami konsep materi maupun ketika sedang menyelesaikan soal. Observasi awal di SMP Negeri 5 Meureubo Kabupaten Aceh Barat juga menunjukkan hal yang sama, yaitu banyaknya kesalahan yang dilakukan oleh siswa ketika menyelesaikan soal matematika. Hasil wawancara secara informal dengan salah satu guru matematika di sekolah tersebut menunjukkan, aljabar merupakan materi yang dirasa paling banyak ditemui kesalahannya. Hal tersebut diperkuat dengan banyak kesalahan yang ditemukan peneliti ketika siswa diminta untuk menyelesaikan soal bentuk aljabar.

NCTM (2008) menyatakan bahwa aljabar adalah suatu cara berpikir dan suatu himpunan konsep dan keterampilan yang memungkinkan siswa untuk menggeneralisasi, memodelkan, dan menganalisis situasi matematis. Aljabar menyediakan suatu cara yang sistematis untuk menyelidiki hubungan, membantu untuk menggambarkan, mengorganisasi, dan memahami dunia. Bentuk aljabar dan persamaan berfungsi sebagai model untuk menafsirkan dan membuat kesimpulan tentang data. Oleh karena itu, penalaran matematika yang dikembangkan melalui aljabar diperlukan sepanjang hidup, memengaruhi keputusan yang kita buat dalam berbagai bidang. Dengan demikian, dapat dikatakan bahwa pemahaman aljabar yang lebih baik dapat meningkatkan kemampuan pengambilan keputusan dalam masyarakat.

Hasil penelitian Egodawatte (2011:131) di Toronto, Kanada menunjukkan sejumlah kategori kesalahan dari masing-masing aspek. Pada aspek variabel, alasan utama terjadi kesalahan adalah kurangnya pemahaman konsep dasar dari variabel dalam konteks yang berbeda. Struktur abstrak pada aspek bentuk aljabar menghadirkan masalah pada siswa seperti masalah dalam memahami atau memanipulasi bentuk aljabar sesuai aturan, prosedur, atau algoritma. Pemahaman yang kurang mengenai penggunaan tanda sama dengan dan sifat-sifatnya bila digunakan dalam persamaan merupakan masalah utama yang menghambat siswa menyelesaikan persamaan dengan benar. Kesulitan utama dalam aspek soal cerita adalah menerjemahkan soal cerita ke dalam bahasa aljabar. Siswa banyak menggunakan metode tebakan atau trial and error dalam menyelesaikan soal cerita. Hall (2001:13) yang dalam penelitiannya menyatakan bahwa mengenai penyederhanaan bentuk aljabar, penggunaan tanda negatif dapat membuat siswa bingung dan meningkatkan banyaknya kesalahan siswa dalam menyelesaikan soal.

Pujisari (2016) mengatakan bahwa terdapat dua macam kesalahan dalam aljabar yaitu kesalahan konseptual dan kesalahan prosedural. Kesalahan konseptual meliputi kesalahan dalam memahami makna soal dan kesalahan dalam memahami konsep soal. Sedangkan kesalahan prosedural meliputi kesalahan dalam menuliskan langkah dan kesalahan dalam perhitungan. 
Penelitian oleh Ihsan (2003:97) yang lebih spesifik pada pecahan bentuk aljabar menyatakan bahwa kesalahan yang dilakukan siswa secara umum dalam menyederhanakan pecahan bentuk aljabar adalah siswa belum memahami konsep pemfaktoran, siswa lupa atau tidak tahu pola pemfaktoran, siswa belum memahami konsep penyederhanaan pecahan bentuk aljabar. Yakin (2011:88) juga menyatakan bahwa kesalahan siswa dalam menyederhanakan pecahan aljabar terletak pada ketidakmampuan dalam memfaktorkan.

Dari beberapa penelitian di atas, pemberian scaffolding untuk membantu siswa dalam meminimalkan kesalahannya belum diterapkan. Sehingga tidak ada tindak lanjut setelah para peneliti tersebut menganalisis maupun menggolongkan kesalahan tiap siswanya. Padahal, pemberian scaffolding sangat penting bagi siswa yang melakukan kesalahan. Proses berpikir siswa dalam penyelesaian masalah bersifat unik, dan secara umum proses berpikir tersebut dapat berkembang dengan pemberian scaffolding (Sujiati, 2011:7). Scaffolding adalah istilah yang digunakan Vygotsky untuk bantuan dari sesorang yang lebih kompeten dalam menyelesaikan masalah dengan tingkat kesulitan di atas kemampuan dasar siswa. Janneke (2010),"Scaffolding adalah bantuan yang diberikan oleh guru ketika peserta didik tidak mampu mengerjakan tugas yang diberikan tanpa adanya bantuan". Bantuan yang diberikan oleh pendidik (guru) dapat berupa petunjuk, peringatan, dorongan, menguraikan masalah ke dalam bentuk lain yang memungkinkan peserta didik dapat mandiri, (Mamin, 2008). Pemberian bantuan harus disesuaikan dengan zona proximal development (ZPD) peserta didik, yang merupakan jarak antara tingkat perkembangan sesungguhnya. Scaffolding merupakan praktik berdasarkan konsep Vgyotsky mengenai ZPD yang dapat diartikan sebagai Daerah Perkembangan Terdekat (Vonna, Mukminatien, dan Laksmi, 2015).

Tujuan diterapkannya scaffolding untuk menggambarkan jenis dukungan terhadap proses yang memungkinkan siswa untuk menyelesaikan masalah, melaksanakan tugas atau mencapai tujuannya (Kolikant dan Broza, 2010:3). Lebih lanjut, siswa dengan kemampuan tinggi ketika menyelesaikan tugas dapat memberikan scaffolding pada siswa dengan kemampuan rendah hingga proses berpikirnya sesuai dengan struktur masalah. Anghileri (2006) di dalam penelitiannya menyampaikan bahwa terdapat 3 level scaffolding yaitu Scaffolding level 1 (environmental provisions), Scaffolding level 2 (explaining, reviewing, and restructuring), dan Scaffolding level 3 (developing conceptual thinking). Scaffolding dalam penelitian ini merupakan bantuan secukupnya dari peneliti untuk siswa yang tidak dapat menyelesaikan masalah pada masing-masing aspek aljabar, yaitu: variabel, bentuk aljabar, persamaan, soal cerita.

Tujuan penelitian ini adalah sebagai berikut: (1) mendeskripsikan kesalahan siswa dalam menyelesaikan soal matematika materi aljabar dan (2) mendeskripsikan upaya pemberian scaffolding untuk membantu 
mengatasi kesalahan siswa dalam menyelesaikan soal matematika materi aljabar.

\section{METODE}

\section{Rancangan Penelitian}

Rancangan penelitian yang digunakan dalam penelitian ini adalah mixed method dua fase, atau yang lebih dikenal dengan Explanatory Design. Lebih khususnya, Explanatory Design model seleksi partisipan. Model seleksi partisipan digunakan ketika peneliti membutuhkan informasi kuantitatif untuk mengidentifikasi dan sengaja memilih peserta untuk tindak lanjut untuk diteliti lebih mendalam dalam penelitian kualitatif. Berikut adalah gambar skema rancangan penelitian sesuai penjelasan di atas.

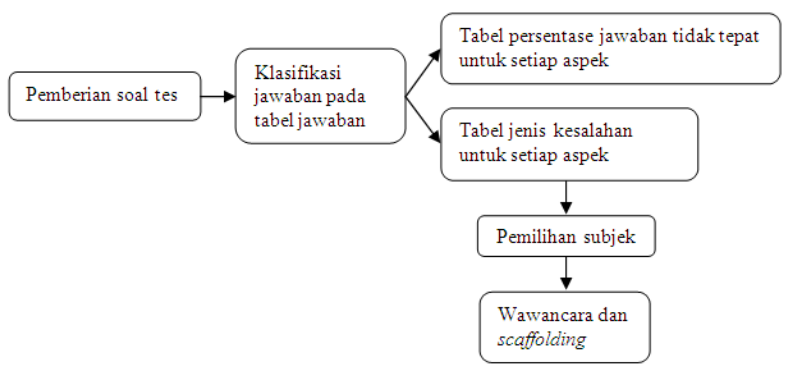

\section{Gambar 1. Skema Rancangan Penelitian}

Penelitian diawali dengan pemberian soal tes materi aljabar kepada siswa kelas VIII di SMP Negeri 5 Meureubo sebanyak 30 siswa. Kemudian jawaban siswa diklasifikasikan ke dalam tabel jawaban untuk setiap nomor soal. Selanjutnya disusun dua tabel, tabel pertama merupakan persentase jawaban tidak tepat untuk setiap aspek. Tabel kedua adalah tabel jenis kesalahan untuk setiap aspek. Tabel pertama untuk menggambarkan pada aspek apa yang paling banyak dan paling sedikit terjadi kesalahan. Sedangkan tabel kedua untuk melihat lebih rinci jenis kesalahan apa saja yang muncul pada setiap aspek. Selanjutnya, tabel dua tersebut dapat membantu peneliti untuk memilih beberapa subjek yang selanjutnya akan diwawancarai secara mendalam dan diberikan scaffolding atas kesalahan yang dilakukan. Selanjutnya dilakukan analisis secara mendalam terhadap setiap jawaban siswa.

\section{Instrumen Penelitian}

Instrumen yang digunakan dalam penelitian adalah lembar soal tes dan lembar pedoman wawancara. Soal tes digunakan pada tahap kuantitatif, sedangkan pedoman wawancara digunakan pada tahap kualitatif.

\section{Lembar Soal Tes}

Soal tes yang digunakan adalah soal tes diagnosis yang dapat mengidentifikasi dan mengarakterisasi kesalahan siswa dalam 
menyelesaikan masalah aljabar. Soal tes disusun oleh peneliti berdasarkan adaptasi dan adopsi dari penelitian sebelumnya, yaitu dari penelitian Egodawatte (2011). Soal tes disusun dan dikonsultasikan dengan pembimbing, guru matematika SMP tempat penelitian, dan divalidasi isi nya oleh para validator. Validator terdiri dari dosen STKIP Bina Bangsa Meulaboh yang berpengalaman dalam bidang pendidikan matematika dan guru matematika SMP Negeri 5 Meureubo. Bentuk soal tes yang diberikan kepada subjek penelitian berupa permasalahan aljabar yang memuat aspek variabel, bentuk aljabar, persamaan aljabar, dan soal cerita aljabar. Alokasi waktu untuk menyelesaikan ketujuh soal tersebut adalah 50 menit.

\section{Lembar Pedoman Wawancara}

Wawancara yang digunakan sesuai model Newman (dalam Egodawatte, 2011) yaitu memuat poin-poin berikut: membaca, komprehensi/interpretasi, pemilihan strategi, proses, pengkodean/penyajian, konsolidasi, verifikasi, dan konflik. Lembar pedoman wawancara ini memuat beberapa pertanyaan baku yang akan diterapkan sama kepada satu subjek dan subjek lainnya, namun dikembangkan peneliti (pewawancara) sesuai jawaban yang mereka tuliskan dalam menyelesaikan soal tes. Pertanyaan wawancara pada lembar pedoman wawancara memuat poin-poin model Newman.

Jenis wawancara yang digunakan dalam penelitian ini adalah wawancara terbuka. Dalam wawancara ini, subjek mengetahui bahwa mereka sedang diwawancarai dan juga mengetahui tujuan wawancara. Wawancara dilakukan terhadap 6 siswa yang dipilih berdasarkan tabel jenis kesalahan. Wawancara dilakukan untuk mengidentifikasi penyebab kesalahan yang telah dilakukan. Dengan wawancara ini diharapkan dapat membantu siswa dalam meminimalkan kesalahannya. Selama wawancara juga dilakukan proses scaffolding. Wawancara dilaksanakan diluar jam pelajaran, dengan harapan tidak mengganggu proses pembelajaran. Semua informasi selama wawancara direkam, dan teknik wawancara diusahakan sedemikian sehingga partisipan tidak merasa terbebani dengan kegiatan wawancara. Jika diperlukan, partisipan diperkenankan menggunakan penjelasan tertulis selama wawancara untuk menguatkan jawabannya.

\section{HASIL DAN PEMBAHASAN}

\section{Kesalahan Siswa dalam Menyelesaikan Masalah Aljabar}

Hasil penelitian menunjukkan bahwa bahwa kesalahan siswa pada aljabar paling banyak terdapat pada aspek soal cerita. Sedangkan kesalahan paling sedikit adalah pada aspek persamaan. Aspek soal cerita mempunyai persentase kesalahan terbesar (81\%), diikuti oleh bentuk aljabar $(72 \%)$, variabel (70\%), dan persamaan (45\%). Menyelesaikan soal cerita sulit bagi siswa karena ada banyak langkah yang diperlukan untuk proses penyelesaian. Selain itu, soal cerita yang diberikan bukan 
merupakan soal yang umum atau yang rutin diselesaikan oleh siswa. Pada aspek bentuk aljabar, siswa melakukan kesalahan dalam mengoperasikan pecahan aljabar. Penyederhanaan yang belum tuntas juga ditemukan dalam pekerjaan siswa. Kurang teliti dalam menyelesaikan operasi pecahan juga merupakan kesalahan yang banyak dilakukan siswa. Pada aspek variabel, beberapa siswa belum memahami soal dengan tepat. Selain itu, ada beberapa siswa yang menganggap konstanta dalam soal tersebut merupakan variabel. Aspek persamaan relatif mudah bagi siswa daripada ketiga aspek sebelumnya.

\section{Kesalahan Siswa pada Aspek Soal Cerita}

Kesalahan Siswa pada Aspek Soal Cerita meliputi: a) Menebak tanpa penalaran; b) Penalaran tidak tepat. Persentase jawaban tertingginya adalah $4 \%$ dan $5 \%$. Aspek soal cerita mempunyai persentase kesalahan terbesar (81\%). Menyelesaikan soal cerita dirasa sulit bagi siswa karena ada banyak langkah yang diperlukan untuk proses penyelesaian. Selain itu, soal cerita yang diberikan bukan merupakan soal yang umum atau yang rutin diselesaikan oleh siswa. Oleh karena itu, pada soal cerita ditemukan kesalahan pada pemahaman makna soal, perumusan metode penyelesaian, dan proses penyelesaian menggunakan suatu metode yang dipilih.

Dalam penelitian ini, ada beberapa siswa yang menebak nebak jawaban dari pertanyaan tanpa alasan atau operasi yang benar. Selain itu, siswa tersebut tidak memverifikasi kebenaran dari jawaban mereka. Mereka tidak mengecek apakah jawaban mereka sudah sesuai/cocok dengan masalah yang diberikan.

Pada kategori ini kesalahan yang ditemukan pada hasil pekerjaan siswa juga beragam. Pertama, ada jawaban akhir siswa yang sudah benar, tetapi prosedur atau operasinya tidak tepat. Ada pula jawaban siswa yang operasi hingga jawaban akhirnya tidak tepat. Ada juga mereka memperoleh jawaban dengan menebak, kemudian baru membuat operasi atau prosedur untuk memperoleh jawaban tersebut, yang mana prosedur tersebut juga tidak tepat jika diterapkan pada masalah yang sama dengan bilangan yang berbeda.

\section{Kesalahan Siswa pada Aspek Variabel}

Jenis kesalahan siswa pada aspek variabel meliputi: a) Memberikan nama (label), nilai yang berubah-ubah, atau kata kerja untuk variabel dan konstanta; b) Kurang memahami konsep "kesatuan" ketika dihadapkan dengan variabel; c) Membentuk persamaan (atau pertidaksamaan) yang salah sebagai jawaban. Temuan yang cukup mencengangkan pada aspek variabel adalah 90\% siswa (27 dari 30 siswa) melakukan kesalahan dalam menentukan variabel yang termuat dalam soal yang berbentuk cerita/pernyataan. Kesalahan tersebut memiliki persentase tertinggi pada aspek variabel yang rata-rata kesalahannya adalah 70\%. Mereka sulit membedakan antara variabel dan bukan variabel dalam permasalahan yang diberikan. Sering kali mereka bingung dengan melihat variabel 
sebagai konstanta atau sebaliknya.

\section{Kesalahan Siswa pada Aspek Bentuk Aljabar}

Pada aspek berikutnya, yaitu aspek aljabar, jenis kesalahannya meliputi: a) Penyederhanaan tidak lengkap; b) Perkalian pecahan tidak tepat; c) Penyederhanaan berlebihan; d) Distribusi yang tidak tepat; e) Kesalahan urutan; f) Beragam jawaban tidak tepat.

Sebanyak 90\% siswa (27 dari 30 siswa) melakukan kesalahan dalam menyederhanakan bentuk aljabar. Beberapa siswa tidak tepat dalam menggunakan sifat distribusi. Distribusi yang tidak tepat adalah semacam penyalahgunaan sifat distributif dalam aljabar. Sifat distributif menyatakan bahwa $a(b+c)=a b+a c$. Ini berarti bahwa kita dapat melakukan penambahan dahulu kemudian mengalikan, atau mengalikan dahulu kemudian menambahkan. Ketika suku tidak sejenis terletak didalam tanda kurung, tidaklah mungkin untuk saling menambahkan mereka. Siswa harus mengalikan tanda kurung dengan suatu huruf diluar kurung tersebut. Sifat distributif membantu kita untuk menyederhanakan sejumlah bentuk aljabar dengan membawa kita untuk mengganti suku yang memuat kurung dengan suku yang tidak memuat kurung.

Temuan selanjutnya adalah $86 \%$ siswa (26 dari 30 siswa) melakukan kesalahan dalam menyederhanakan bentuk aljabar $x\left(\frac{a}{b}\right)$. Dari 76 siswa tersebut, paling banyak hasil akhirnya adalah $\frac{x a}{x b}$ sebanyak $35 \%$, diikuti $\frac{a x}{b x}$ sebanyak $21 \%$. Kesalahan tersebut memiliki persentase tertinggi pada aspek bentuk aljabar yang rata-rata kesalahannya adalah $72 \%$. Ketika siswa mengalikan suatu pecahan aljabar dengan suatu huruf yaitu seperti $x\left(\frac{a}{b}\right)$, mereka sering mengalikan pembilang dan penyebut dengan huruf tersebut, yaitu menjadi $\frac{x a}{x b}$ atau $\frac{a x}{b x}$. Kadang-kadang, mereka berasumsi bahwa tidak ada penyebut pada huruf tersebut. Hal ini sering terjadi pada siswa ketika tidak ada penyebut yang terlihat. Mereka tampaknya memiliki kesulitan dalam menyadari bahwa satu huruf dapat dinyatakan oleh pecahan aljabar dengan membuat 1 sebagai penyebutnya. Karena kekurangpahaman ini, siswa cenderung menganggap bahwa pembilang dan penyebut harus keduanya dikalikan dengan huruf tersebut.

\section{Kesalahan Siswa pada Aspek Persamaan Aljabar}

Kesalahan Siswa pada Aspek Persamaan Aljabar meliputi: a) Bilangan sebagai nama (label); b) Salah mengartikan metode eliminasi dalam menyelesaikan persamaan. Salah satu temuan pada aspek ini adalah 14\% siswa (11 dari 80 siswa) melakukan kesalahan dalam menyelesaikan persamaan $3 x+21=54$. Kesalahan tersebut memiliki 
persentase terendah pada aspek persamaan, bahkan juga terendah dari semua jenis kesalahan pada semua aspek. Seorang siswa menggunakan suatu bilangan sebagai nama (label) untuk mengganti atau mensubstitusi suatu variabel. Cari selesaian untuk $x: 3 x+21=54$, siswa ini menuliskan $x=3$ dengan maksud menyisipkan bilangan 3 ke dalam posisi variabel $x$ untuk mendapatkan 33. Siswa ini mengerti sifat ekuivalensi dan dia menghasilkan bilangan yang benar untuk membuat persamaan tersebut benar, meskipun dia tidak mengikuti prosedur penyelesaian persamaan. Kesalahan ini muncul karena pengetahuan awal siswa tentang persamaan bilangan dimana siswa harus memasukkan bilangan untuk memenuhi persamaan tersebut. Sama halnya, siswa ini menggunakan bilangan sebagai nama (label) untuk huruf untuk memenuhi persamaan tersebut.

Temuan selanjutnya adalah ketika mengeliminasi/menghilangkan variabel dari suatu sistem persamaan linier, beberapa siswa salah menentukan operasi yang akan dilakukan. Beberapa dari mereka memilih operasi sebaliknya, misalnya menambahkan ketika harus mengurangi atau sebaliknya. Mungkin kesalahpahaman ini datang dari pemahaman mereka yang belum kokoh mengenai menyederhanakan bilangan bulat dan memanipulasi tanda. Kesulitan mereka diperparah ketika variabel di dua persamaan saling berlawanan tanda $(+a,-a)$.

Aspek persamaan merupakan aspek paling sedikit kesalahan diantara semua aspek yang diteliti. Hal ini ditunjukkan dengan hanya ditemukan kesalahan sebesar $45 \%$ pada aspek ini. Soal yang diberikan merupakan soal yang menuntut siswa menentukan solusi yang tepat pada suatu persamaan linier. Sebagian besar siswa sudah menjawab dengan tepat. Dari sini dapat kita lihat bahwa siswa sudah terbiasa menyelesaikan soal yang berhubungan dengan prosedural daripada soal pemahaman konsep.

\section{Upaya Pemberian Scaffolding untuk Membantu Mengatasi Kesalahan Siswa dalam Aljabar}

Berikut adalah upaya scaffolding yang diberikan kepada masingmasing subjek yang telah dipilih. Pemilihan subjek berdasarkan kesalahan yang dilakukan sesuai kelompok kesalahan yang ditemukan pada tahap kuantitatif. Untuk tahap kualitatif ini, telah dipilih enam subjek, yaitu S1 untuk aspek variabel, S2 untuk aspek bentuk aljabar, S3 dan S4 untuk aspek persamaan, S5 dan S6 untuk aspek soal cerita.

\section{Pemberian Scaffolding S1}

Berdasarkan wawancara, S1 sebenarnya sudah paham makna dari suatu variabel. Namun, dia mengalami kesulitan saat menentukan variabel pada pertanyaan yang diberikan. Dia menuliskan variabelvariabelnya dan memberi nama (label) untuk mereka. Seharusnya, hal itu tidak perlu dilakukan. Cukup dengan menuliskan variabel saja seperti $y$, $x$, atau yang lain sesuai pertanyaan. Pada wawancara mengenai pertanyaan nomor 2 , setelah diberi pertanyaan dan sedikit pernyataan 
bantuan, S1 pun menyadari sendiri kekurangannya. Dia paham bahwa yang dituliskannya adalah kurang tepat. Yang seharusnya ditulis harga buku, olehnya ditulis buku saja. Akhirnya S1 mengklarifikasi bahwa jawaban yang benar adalah $3 a+2 b$ menyatakan total harga untuk 3 buku dan 2 penggaris.

\section{Pemberian Scaffolding S2}

S2 kurang lengkap dalam menyederhanakan bentuk aljabar yang diberikan. Hasil akhir yang ditulisnya bukan merupakan bentuk aljabar yang paling sederhana. Setelah diberi sedikit pertanyaan arahan dari peneliti, S2 pun mampu menyederhanakan bentuk aljabar tersebut dengan lengkap hingga sampai pada bentuk yang paling sederhana.

Pada soal lain, S2 melakukan kesalahan berupa pengalian pecahan yang kurang tepat. S2 mengalikan $x$ dengan pembilang dan juga dengan penyebut. Yang tentu saja hal itu tidak tepat. Setelah diberi pertanyaan arahan dari peneliti, S2 pun bisa memahami bahwa yang dikerjakannya adalah tidak tepat. S2 pun bisa memperbaiki jawabannya hingga mendapatkan hasil akhir yang tepat, yaitu $x$ hanya dikalikan dengan penyebut, sehingga S2 menuliskan jawaban yang benar adalah $\frac{a x}{b}$.

Pada pertanyaan lain, S2 belum lengkap dalam menyederhanakan bentuk aljabar. Hasil akhir pada jawabannya bukan merupakan bentuk aljabar yang paling sederhana. Setelah diberikan scaffolding berupa pertanyaan arahan, S2 mampu memahaminya dan melengkapi penyederhanaan bentuk aljabar tersebut. Dia pun menuliskan hasil akhir yang tepat sesuai yang diharapkan.

\section{Pemberian Scaffolding S3}

S3 menganggap $x$ pada suku $3 x$ adalah hanya sebagai nama (label). Dia pun mengganti $x$ dengan angka 3 . S3 memahami cara menyelesaikan soal tersebut hanya sampai $3 x=33$. Dia tidak memahami dengan benar makna dari $3 x$. dia menganggap $x$ hanyalah label, sehingga dia menjawab $x=3$. Setelah peneliti memberikan scaffolding berupa pertanyaan arahan, S3 pun paham dimana letak kesalahannya. Dia pun paham makna dari $3 x$, yaitu 3 dikali dengan $x$. Sehingga dia mampu menyelesaikan persamaan dengan tepat dengan memperoleh hasil $x=11$. Untuk menguji pemahamannya, peneliti memberikan soal lain yang sejenis. S3 pun mampu menyelesaikan soal tersebut dengan tepat.

\section{Pemberian Scaffolding S4}

S4 sempat mengalami kebingungan ketika ditanyai mengenai pertanyaan nomor $5 \mathrm{~b}$ pada gambar 2 berikut.

5 b. Selesaikanlah sistem persamaan berikut.

$$
\begin{aligned}
& 2 x-3 y=6 \\
& x+4 y=47
\end{aligned}
$$

Gambar 2. Soal nomor 5b 
S4 bingung antara menambahkan atau mengurangkan kedua persamaan di sistem persamaan tersebut, setelah mengalikan persamaan kedua dengan 2. Namun, setelah diberi scaffolding berupa pertanyaan arahan yang berkaitan dengan penggunaan tanda plus dan minus pada suatu bilangan, S4 pun mengerti dan mampu menyelesaikan pertanyaan dengan benar. S4 juga mampu menuliskan langkah-langkah eliminasi dan substitusi dengan tepat.

\section{Pemberian Scaffolding S5}

Gambar 3 di bawah ini menunjukkan soal nomor 6 diselesaikan oleh S5.

\section{Susi membayar 2 pensil dan 1 penggaris dengan harga $R p 18.000,00$. Sedangkan harga 3 pensil dan 2 penggaris dengan harga Rp 22.000,00. Berapakah Susi harus membayar jika ia membeli 1 pensil dan 2 penggaris?}

\section{Gambar 3. Soal nomor 6}

Soal di atas telah diselesaikan S5 dengan hasil akhir yang tepat, namun masih terdapat kekurangan pada prosesnya. Saat dikonfirmasi untuk mengklarifikasi, ternyata S5 sudah benar-benar paham maksud pertanyaannya. Hanya saja dia tidak menuliskan pemisalannya menyatakan apa di awal proses penyelesaian. Setelah diminta menuliskan kekurangannya, S5 mampu menuliskannya dengan tepat yaitu memisalkan banyaknya pensil dengan variabel $s$ dan banyaknya penggaris dengan variabel $p$.

\section{Pemberian Scaffolding S6}

Proses penyelesaian dan hasil akhir yang dituliskan pleh S6 atas pertanyaan "Berapa kali umur Tina kah umur ayah 12 tahun lagi, jika sekarang umur ayah 6 kali umur Tina, dan umur ayah 48 tahun?" tidak tepat. Setelah diberi scaffolding berupa pertanyaan arahan, S6 pun mampu menjawabnya dengan dua cara yang berbeda. Yaitu yang pertama dengan cara aritmetika biasa, yaitu mengecek tiap tahun sampai ketemu umur ayah tiga kali umur Tina. Cara yang kedua adalah cara aljabar yang bentuk aljabarnya disusun oleh siswa sendiri dengan bantuan pertanyaan arahan dari peneliti. Setelah diselesaikan kembali oleh S6, akhirnya diperoleh hasil akhir yang tepat baik dengan cara pertama maupun dengan cara kedua.

Hasil dan pembahasan yang telah diuraikan di atas didukung oleh Hall (2001:13) yang dalam penelitiannya menyatakan bahwa mengenai penyederhanaan bentuk aljabar, penggunaan tanda negatif dapat membuat siswa bingung dan meningkatkan banyaknya kesalahan siswa dalam menyelesaikan soal. Penyebab utama atas kesalahan ini adalah kekurangpahaman konsep aritmetika atau kegagalan transfer pemahaman aritmetika ke konteks aljabar (Stacey dan Chick, 2004; Stacey dan MacGregor, 1999). Selain itu, kesalahan yang ditemukan pada aspek soal cerita didukung oleh Egodawatte (2011:151) yang menyatakan bahwa soal cerita adalah hal yang paling bermasalah bagi siswa. Mereka kesulitan 
menyelesaikan karena harus melewati tiga tahap: menerjemahkan menjadi bentuk matematis, menyelesaikannya, dan menyatakan hasilnya. Siswa membutuhkan kerja tambahan untuk menyelesaikan soal cerita karena suatu soal cerita memuat konsep yang saling terkait satu dengan yang lain diantara ketiga aspek lainnya (variabel, bentuk aljabar, persamaan). Sesuai dengan tujuan diterapkannya scaffolding untuk menggambarkan jenis dukungan terhadap proses yang memungkinkan siswa untuk menyelesaikan masalah, melaksanakan tugas atau mencapai tujuannya (Kolikant dan Broza, 2010:3), scaffolding dalam penelitian ini berhasil membuat siswa dalam penelitian dapat memahami kesalahan yang dilakukan dan menyelesaikan permasalahan yang dihadapi.

\section{KESIMPULAN DAN SARAN Kesimpulan}

Dari penjelasan di atas, dapat disimpulkan bahwa hasil penelitian menunjukkan kesalahan siswa pada aljabar paling banyak terdapat pada aspek soal cerita dan paling sedikit pada aspek persamaan. Aspek soal cerita mempunyai persentase kesalahan terbesar $(81 \%)$, diikuti oleh bentuk aljabar $(72 \%)$, variabel $(70 \%)$, dan persamaan $(45 \%)$. Kesalahan pada aspek soal cerita: menebak tanpa penalaran; penalaran tidak tepat. Kesalahan pada aspek bentuk aljabar: penyederhanaan tidak lengkap; perkalian pecahan tidak tepat; penyederhanaan berlebihan; distribusi yang tidak tepat; kesalahan urutan; beragam jawaban tidak tepat. Kesalahan pada aspek variabel: memberikan nama (label), nilai yang berubah-ubah, atau kata kerja untuk variabel dan konstanta; kurang memahami konsep "kesatuan" ketika dihadapkan dengan variabel; membentuk persamaan (atau pertidaksamaan) yang salah sebagai jawaban. Kesalahan pada aspek persamaan: bilangan sebagai nama (label); salah mengartikan metode eliminasi dalam menyelesaikan persamaan. Setelah pemberian scaffolding, keenam siswa yang diwawancarai selama penelitian menjadi paham letak kesalahannya dan mampu menyelesaikan pertanyaan yang diberikan dengan tepat.

Eksplorasi yang lebih rinci dari kesalahan dalam aljabar merupakan prasyarat penting bagi setiap upaya lebih lanjut untuk meningkatkan kualitas pendidikan matematika dan pengetahuan siswa. Dengan memperhatikan masalah ini, hasil penelitian ini diharapkan dapat menginformasikan kepada guru, perencana kurikulum, penulis buku, dan pemangku kepentingan lainnya untuk memperluas pemahaman mereka tentang bagaimana kesalahan dalam aljabar dapat diidentifikasi dan merupakan hal yang penting dalam kehidupan. Jadi, jika peneliti dapat mengetahui dan menjelaskan cara-cara pemahaman siswa dalam aljabar dengan cara rinci, akan lebih mudah bagi para guru dan peneliti untuk merancang pembelajaran yang efektif untuk meningkatkan pemahaman siswa. 


\section{Saran}

Setelah penelitian ini dilakukan, peneliti berharap peneliti lain mengembangkan penelitian serupa dalam hal pemberian scaffolding terhadap permasalahan siswa dalam menyelesaikan soal matematika. Selain itu, peneliti berharap terdapat penelitian pengembangan mengenai rangkaian bantuan atau tindakan scaffolding secara rinci sesuai dengan permasalahan yang dihadapi siswa sehingga tujuan pembelajaran di setiap tingkat pendidikan dapat tercapai dengan maksimal.

\section{DAFTAR RUJUKAN}

Anghileri, J. 2006. Scaffolding Pactices that Enhance Mathematics Learning. Journal of Mathematics Teacher Education.

Egodawatte, G. 2011. Secondary School Students' Misconceptions in Algebra. Tesis tidak diterbitkan. Toronto: University of Toronto.

Hall, R D. G. 2001. An Analysis of Thought Processes during Simplification of an Algebraic Expression. UK: Exeter University.

Ihsan. 2003. Mendiagnosis dan Membantu Kesulitan Siswa dalam Menyederhanakan Pecahan Bentuk Aljabar di Kelas III SLTP PGRI 6 Malang. Tesis tidak diterbitkan. Malang: Pascasarjana UM.

Janneke, VDP, Volman, M dan Beishuizen, J. 2010 Scaffolding in TeacherStudent Interaction: A Decade of Research. Education Psychology Review. (22): 271-296.

Kolikant,Y.B. \& Broza, O. 2010. The effect of using a video clip presenting a contextual story on low-achieving students' mathematical discourse. Jerusalem: The Hebrew University of Jerusalem.

Mamin, R. 2008. Penerapan Strategi Pembelajaran Scaffolding pada Pokok Bahasan Sistem

Periodik Unsur. Jurnal Chemica. 10 (2): 55-60.

NCTM (National Council of Teachers of Mathematics). 2008. Algebra: What, When, and for Whom. A Position of the National Council of Teachers of Mathematics, (Online), (http://www.nctm.org/about/content.aspx? id=16229), diakses 15 Desember 2019.

Pujisari, Anisa. 2016. Analisis Kesalahan Siswa dalam Menyelesaikan Bentuk Aljabar. Surakarta: Universitas Muhammadiyah Surakarta.

Sujiati, A. 2011. Proses Berpikir Siswa dalam Pemecahan Masalah dengan Pemberian Scaffolding. Tesis tidak diterbitkan. Malang: Program Pascasarjana Universitas Negeri Malang.

Stacey, K. \& MacGregor, M. 1999. Taking the Algebraic Thinking Out of Algebra. Mathematics Education Research Journal, 1, 24-38.

Vonna, Y., Mukmanatien, N., dan Laksmi, E.D. 2015. The Effect of Scaffolding Techniques on Students' Writing Achievement. Jurnal Pendidikan Humaniora. 3 (1): 227-233.

Yakin, M.H.A. 2011. Diagnosis Kesulitan Siswa dalam Menyederhanakan Pecahan Aljabar dan Upaya Mengatasinya dengan Menggunakan Scaffolding. Tesis tidak diterbitkan. Malang: Pascasarjana UM. 